\title{
CHANGES IN PHYSICAL, MECHANICAL, SHRINKING AND SWELLING PROPERTIES OF PINE WOOD SPECIES TREATED WITH SALT NATURAL GEOTHERMAL WATERS AS ENVIRONMENTALLY SAFE RESOURCES
}

\author{
VAR, A. A. ${ }^{*}$ KARDAŞ, İ. \\ Department of Forest Biology and Wood Preservation Technology, Faculty of Forestry, Isparta \\ University of Applied Sciences, 32260 Cunur, Isparta, Turkey \\ (phone: + 90-246-211-4986; fax: +90-246-211-3948) \\ *Corresponding author \\ e-mail: alivar@isparta.edu.tr; phone: +90-533-760-2309; fax: +90-246-211-3948
}

(Received 27 $7^{\text {th }}$ May 2019; accepted 28 $8^{\text {th }}$ Aug 2019)

\begin{abstract}
The purpose of this study was to study the effects of salt natural geothermal water (SNGW) treatment on the physical, mechanical, shrinking and swelling properties of wood materials from two pine species. This study used the SNGW of Eynal, Çitgöl, and Naşa from Kutahya in Turkey on sapwood samples of black pine (Pinus nigra Arnold.) and Brutia pine (Pinus brutia Ten.). The absorption, retention, density, moisture content, modulus of rupture (MOR), modulus of elasticity in bending (MOE), compression strength parallel to the grain (CSPG), shrinking, and swelling values were measured for the treated and non-treated wood samples. The results showed that the absorption and retention values increased by depending on the concentrations of the dissolved salts in the SNGW used. In addition, the density and moisture content values of the SNGW-treated pine wood species were significantly higher than those of the untreated wood, whereas the values of MOR, MOE, CSPG, shrinking, and swelling were lower. In general, the Eynal treatment had the highest effect on pine species' wood properties, whereas the Naşa treatment had the least effect.
\end{abstract}

Keywords: renewable, preservative, impregnation, ecofriendly, treatment

\section{Introduction}

The idea of eliminating the environmentally harmful aspects of industrial processes has led researchers to develop not only new alternative resources but also new environmentally compatible wood preservatives. New alternatives alleviate some environmental problems caused by the wood preservative industry. Hence, natural resources have been used and preferred for worldwide application to limit and control pollution (Bozkurt et al., 1993). SNGW can be considered as an environmentally safe sustainable natural resource for wood preservatives. In recent years, research into wood preservatives has led to the development of several new methods that are able to produce pine wood with properties near those treated by conventional methods. The use of SNGW in the impregnation processes is a new idea and could be a useful approach.

It is well-known that geothermal waters naturally contain high amounts of dissolved chemicals, including various mineral salts; and this resource is valuable for different areas, such as heating, livestock farms, drying of organic materials, recreation, and health tourism, all of which depend on the water temperature and the chemicals contained in the water. In this regard, the use of geothermal waters has expanded appreciably from agriculture, livestock, and medical applications (Ilgar, 2005).

Moreover, wood impregnation with preservatives is a process that often uses synthetic and toxic chemicals that are not environmentally compatible. New 
environmentally safe chemicals are needed to preserve the wood that is used for indoor and outdoor applications. Due to their high levels of dissolved mineral salts, geothermal waters have potential as wood preservatives, in which this resource may resolve some environmental issues facing the wood preservative industry. For this reason, these salt natural waters should be studied as a wood preservative agent.

To date, much research has been conducted on the physical, mechanical, shrinking and swelling properties of various impregnated wood species. Examples of these species are European beech, pine, spruce, Scots pine, yellow poplar, and red oak treated with waterborne preservatives such as chromated copper arsenate (CCA), ammoniacal copper arsenate (ACA), ammoniacal copper zinc arsenate (ACZA), and alkaline copper quaternary (ACQ) compounds (Winandy, 1995); pine treated with linseed oil (Megnis et al., 2002); yellow pine treated with CCA, ACQ-1900, ACQ-2200, Tanalith-E 3491, and Wolmanit CX-8 (Yildiz et al., 2004); oriental beech, oak, Scots pine, oriental spruce, and Uludag fir treated with Imersol-Aqua (Ors et al., 2005); pine and American beech treated with copper chloride, sodium borate, and phenol-formaldehyde resinpyrolytic oil (Mourant et al., 2007); jack pine and sugar maple treated with copper chloride, copper chloride-sodium borate mixture, and phenol formaldehyde-pyrolytic oil resins (Mourant et al., 2008); beech and pine treated with aqueous solution of borates (Simsek et al., 2010); rowan treated with Tanalith-E, Vacsol Azure, Imersol-Aqua, borax, and boric acid (Keskin et al., 2013); fir treated with citric acid (Ville et al., 2014); oriental beech treated with Turkish sweetgum balsam as an aromatic resinous wood preservative (Degirmentepe et al., 2015); and beech, walnut, poplar, ash, and pine treated with Tanalith-E (Keskin and Daglioglu, 2016); shrinking and swelling minimization of wood treated with the synthetic resin-forming materials (Stamm and Seborg, 1936); beech wood impregnated with $\mathrm{NH}_{3}$ (Bariska, 1975); Corsican pine wood treated with ammonia (Coles and Walker, 1978); swelling of wood in liquid ammonia (Stamm, 1955). Some of the wood preservatives mentioned above are now prohibited in several countries, and are being used less frequently in other countries due to their negative impacts to the environment. Currently, new research is being conducted to develop new impregnation agents for wood preservation.

In contrast, the economic use of SNGW could only be possible by evaluating the dissolved chemicals in those waters, including various minerals. However, there are few studies that evaluate geothermal water properties. Var (2009) discussed whether geothermal waters could potentially be used for wood preservation. Another study reported results that included absorption, retention, and swelling values of Brutia pine treated with geothermal waters from Izmir, Turkey (Var et al., 2013). A third study examined the effects of condensed geothermal waters from Aydin, Turkey on wood properties (Yaldiz and Var, 2017). In these investigations, which study the wood treated with geothermal waters, a definite result was not obtained regarding the wood's physical and mechanical properties. The potential wood impregnants content in geothermal waters was observed, as well as some properties such as absorption, retention, and swelling of wood treated with such natural saltwater. Also, this observation showed that more than half of the naturally dissolved minerals contained in the SNGW could be used as potential wood preservative in the wood preservation formulations; the absorption and retention properties of treated wood had increased due to the concentration of naturally dissolved salts in the SNGW; the swelling properties of treated wood decreased compared to the untreated control wood. However, it has been noted that there are few studies that have reported the physical, mechanical, shrinking 
and swelling properties of wood that was impregnated with preservatives. For instance, Var et al. (2017) only examined the modulus of elasticity and compressive strength of wood impregnated with hot geothermal waters. Sen et al. (2017) only reported some of the mechanical properties of wood treated with geothermal and mineral waters.

It should be realized that geothermal waters contain diverse mineral salts at various concentrations. These natural resources could be useful as waterborne wood impregnation agents for wood preservation (Var, 2009). It is known that waterborne wood impregnation agents affect the mechanical properties of wood. These effects can be related to many factors, such as types of dissolved mineral salts within the natural water, types of woods treated, sizes and grades of woods being treated, and environmental conditions of wood exposure; other influencing factors include the type of preservative used and its retention. However, the effects of SNGW on wood properties have not been reported. Such studies are needed to determine if SNGW have certain effects on the properties of wood.

In this paper, the goal is to investigate the effects of treatment with various SNGW on the physical, mechanical, shrinking and swelling properties of various pine wood species. The SNGW contain various inorganic ions such as chloride, sodium, calcium, sulfate, potassium, magnesium, silicate, fluoride, boron, ammonia, and borate. These inorganics are used as water-based wood preservatives added to wood preservative formulations (Var, 2009). When pine wood materials are treated with SNGW, such dissolved ions can affix to the cell walls, lumens, and intercellular spaces, or react with wood constituents, to result in precipitates within the wood structure. In contrast, it is still challenging to find natural and environmentally compatible processes for wood protection. Hence, the determination of effects on such properties of pine wood of the natural saltwaters can be useful as an environmentally friendly wood preservative. In this sense, the use of SNGW in the wood protection systems can also reduce the environmental problems related to the health and ecology when compared to other conventional wood preservatives.

\section{Materials and methods}

\section{Materials}

\section{Preparation of wood specimens}

Two different pine wood species, black pine (Pinus nigra Arnold.) and Brutia pine (Pinus brutia Ten.), were collected from a natural forest located in Isparta, Turkey. The specimens were obtained from air-dried sapwood portions in the radial direction in accordance to ISO 3129 (2012) standard. Clear and defect-free specimens were prepared with the following dimensions: $30 \mathrm{~mm}$ radial $(\mathrm{R}) \times 30 \mathrm{~mm}$ tangential $(\mathrm{T}) \times$ $15 \mathrm{~mm}$ longitudinal (L) for the absorption and retention tests; $20 \mathrm{~mm} \mathrm{R} \times 20 \mathrm{~mm} \mathrm{~T} \times$ $30 \mathrm{~mm} \mathrm{~L}$ for the density, moisture content, shrinking and swelling tests; $20 \mathrm{~mm} \mathrm{R} \times$ $20 \mathrm{~mm} \mathrm{~T} \times 300 \mathrm{~mm}$ L for the modulus of rupture (MOR) and modulus of elasticity in bending (MOE) tests; and $20 \mathrm{~mm} \mathrm{R} \times 20 \mathrm{~mm} \mathrm{~T} \times 100 \mathrm{~mm} \mathrm{~L}$ for the compression strength parallel to grain (CSPG) tests. Prior to wood impregnation treatments, 15 samples for each test were placed in a conditioning cabinet, and held at a relative humidity of $65 \% \pm 3 \%$ and temperature of $20{ }^{\circ} \mathrm{C} \pm 2{ }^{\circ} \mathrm{C}$ until a stable mass was obtained in accordance to the ISO 13061-1 (2014) standard. To avoid potential 
fluctuations in the moisture content, the samples were placed into plastic bags and stored until the treatments were conducted.

\section{Preparation of SNGW}

SNGW was obtained from the Eynal (E-6), Çitgöl (C-1), and Naşa (N-1) geothermal fields of Kutahya, Turkey (Table 1; Fig. 1). These waters were refrigerated at $23{ }^{\circ} \mathrm{C} \pm 2{ }^{\circ} \mathrm{C}$ in 20 -L containers. The SNGW was used without filtration and sterilization in the wood impregnation processes. The chemical compositions of SNGW, their concentrations, and their dosage levels have been described in Var et al. (2015). This study reported that SNGW contained boron, sodium, potassium, calcium, magnesium, arsenic, chlorine, fluorine, aluminum, silicon dioxide, sulfate, and ammonia. Also, the study determined that the highest concentration $(1930.47 \mathrm{mg} / \mathrm{L})$ was for the E-6 geothermal, and the lowest concentration $(1421.56 \mathrm{mg} / \mathrm{L})$ was for the N-1 geothermal.

Table 1. The GPS coordinates of the survey localities from Turkey's Kutahya province

\begin{tabular}{c|c}
\hline Survey localities & GPS coordinates \\
\hline Eynal & $39.126875,28.995479$ \\
Çitgöl & $39.132907,28.967043$ \\
Naşa & $39.143784,28.961431$ \\
\hline
\end{tabular}

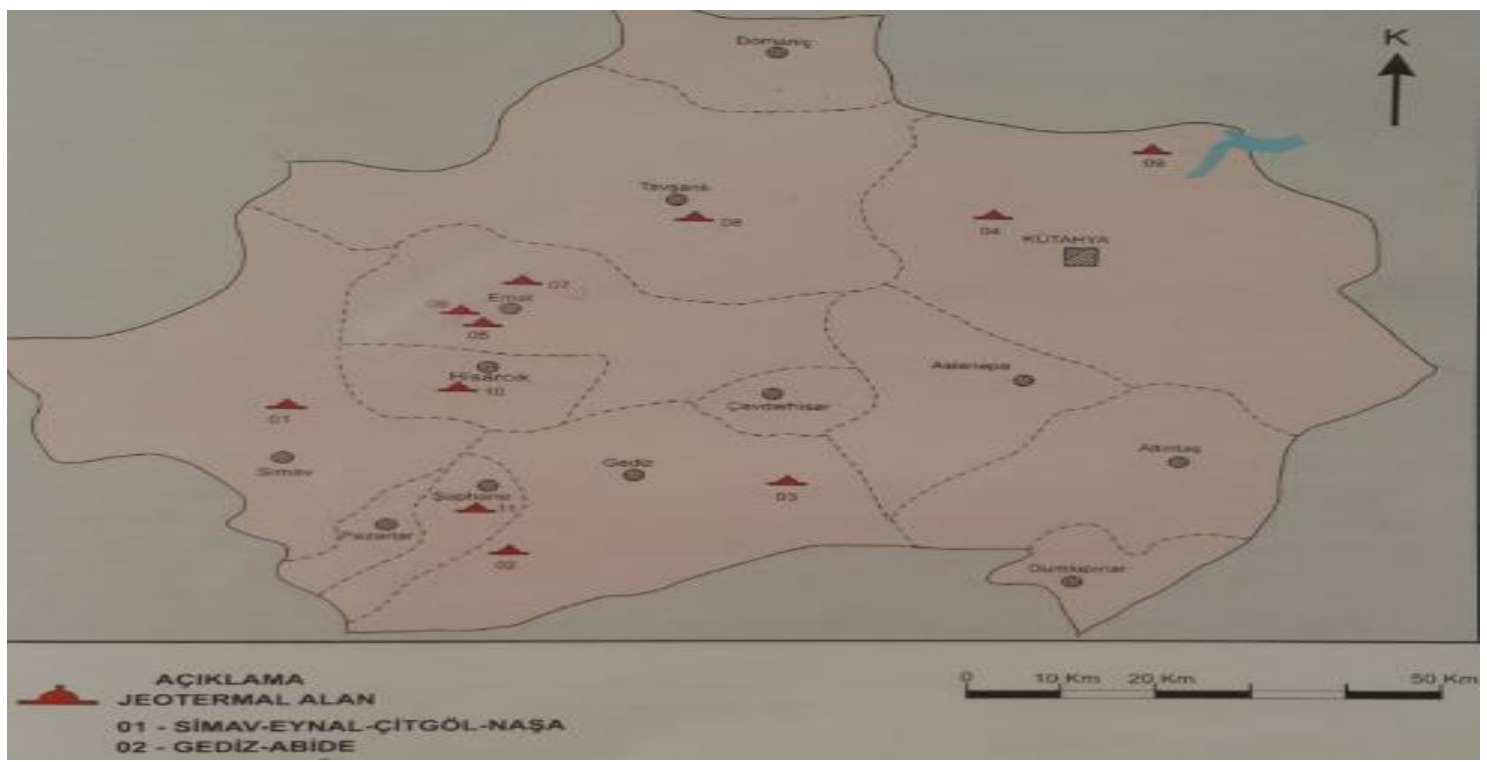

Figure 1. Geothermal area map of the survey localities in Kutahya, Turkey (Akkuş et al., 2005)

\section{Methods}

\section{Treatment process}

The treatment process was performed at room temperature in the laboratory. Wood samples were treated with one of the three SNGW in accordance to the ASTM D141307e1 (2007) standard. A dipping treatment was used for the wood impregnation process. 
The samples were immersed in the selected SNGW for $24 \mathrm{~h}$. After the treatment, the excess SNGW was wiped off the surfaces of the sample. The treated specimens were immediately weighed to determine the gross SNGW uptake; afterwards, the specimens were then conditioned at $20{ }^{\circ} \mathrm{C} \pm 2{ }^{\circ} \mathrm{C}$ and $60 \% \pm 3 \%$ relative humidity prior to physical, mechanical, swelling, and shrinking testing in accordance to ISO 13061-1 (2014).

\section{Measurement of physical properties}

The physical properties of the wood samples were determined in accordance to the following international laboratory standards: ASTM D1413-07e1 (2007) for absorption and retention values, ISO 13061-2 (2014), for density measurement, and ISO 13061-1 (2014) for moisture content measurement.

\section{Measurement of mechanical properties}

The mechanical properties of the wood samples were determined in accordance to the following international laboratory standards: ISO 13061-3 (2014) for modulus of rupture in bending (MOR), ISO 13061-4 (2014) for modulus of elasticity in bending (MOE), and ISO 13061-17 (2017) for compression strength parallel to the grain (CSPG). Mechanical tests were performed with a $4000 \mathrm{kp}$ universal testing machine (Marestek, Istanbul, Turkey) using a constant $6 \mathrm{~mm} \cdot \mathrm{min}^{-1}$ crosshead speed.

\section{Measurement of shrinking and swelling properties}

The shrinking and swelling properties for the wood samples were determined accordance to the following international laboratory standards: ISO 4469 (1981) for radial and tangential shrinking, ISO 4858 (1982) for volumetric shrinking, ISO 4859 (1982) for radial and tangential swelling, ISO 4860 (1982) for volumetric swelling, and Kantay (1978) and Bozkurt et al. (1993) for anisotropic shrinking and swelling.

\section{Statistical analysis of data}

The data collected from the experimental measurements were analyzed using an analysis of variance (ANOVA) at a 95\% significance level $(\mathrm{p} \leq 0.05)$; statistical comparisons among the groups were made using the Duncan test. A computerized program, SPSS 20 Statistics (IBM Corp., New York, NY, USA), was used for the analyses. Statistical evaluations via the Duncan test were made using homogeneity groups, in which different letters reflected significant differences among the groups.

\section{Results and discussion}

\section{Physical properties}

Table 2 shows the physical data for absorption, retention, density, and moisture content tests for both pine species treated with salt natural geothermal waters. It appeared that the SNGW had a clear effect on these physical properties. The E-6 treatment yielded the highest measured physical values for both wood species. For black pine, the highest absorption $(2.06 \mathrm{~g})$, retention $\left(0.60 \mathrm{~kg} / \mathrm{m}^{3}\right)$, density $\left(0.56 \mathrm{~g} / \mathrm{cm}^{3}\right)$, and moisture content $(9.89 \%)$ values were obtained. Likewise, for Brutia pine, the highest values for absorption of $2.41 \mathrm{~g}$, retention of $0.72 \mathrm{~kg} / \mathrm{m}^{3}$, density of $0.59 \mathrm{~g} / \mathrm{cm}^{3}$, and 
moisture content of $10.57 \%$ were observed for the E- 6 treatment. Furthermore, the N-1 treatment yielded the lowest measured physical values of $1.82 \mathrm{~g}$ (absorption), $0.48 \mathrm{~kg} / \mathrm{m}^{3}$ (retention), $0.53 \mathrm{~g} / \mathrm{cm}^{3}$ (density), and $9.44 \%$ (moisture content) for black pine, and $2.15 \mathrm{~g}$ (absorption), $0.52 \mathrm{~kg} / \mathrm{m}^{3}$ (retention), $0.58 \mathrm{~g} / \mathrm{cm}^{3}$ (density), and $9.93 \%$ (moisture content) for Brutia pine.

Table 2. Physical properties of pine wood species treated with SNGW

\begin{tabular}{c|c|c|c|c|c}
\hline $\begin{array}{c}\text { Wood } \\
\text { species }\end{array}$ & $\begin{array}{c}\text { Geothermal } \\
\text { water }\end{array}$ & Absorption (g) & Retention $\left(\mathbf{k g} / \mathbf{m}^{\mathbf{3}}\right)$ & Density $\left(\mathbf{g} / \mathbf{c m}^{\mathbf{3}}\right)$ & Moisture (\%) \\
\hline & Control* & - & - & $0.52(0.05) \mathrm{e}$ & $9.11(0.70) \mathrm{h}$ \\
Black pine & $\mathrm{N}-1$ & $1.82\left(0.22^{* *}\right) \mathrm{a}$ & $0.48(0.04) \mathrm{c}$ & $0.53(0.04) \mathrm{ef}$ & $9.44(0.83) \mathrm{h}$ \\
& $\mathrm{C}-1$ & $1.96(0.16) \mathrm{ab}$ & $0.56(0.12) \mathrm{d}$ & $0.55(0.04) \mathrm{ef}$ & $9.75(0.79) \mathrm{i}$ \\
& $\mathrm{E}-6$ & $2.06(0.44) \mathrm{b}$ & $0.60(0.08) \mathrm{d}$ & $0.56(0.06) \mathrm{f}$ & $9.89(0.24) \mathrm{i}$ \\
\hline & Control* & - & - & $0.57(0.06) \mathrm{p}$ & $9.26(0.48) \mathrm{q}$ \\
Brutia pine & $\mathrm{N}-1$ & $2.15(0.31) \mathrm{j}$ & $0.52(0.07) \mathrm{l}$ & $0.58(0.07) \mathrm{p}$ & $9.93(0.56) \mathrm{r}$ \\
& $\mathrm{C}-1$ & $2.24(0.26) \mathrm{jk}$ & $0.63(0.09) \mathrm{m}$ & $0.58(0.05) \mathrm{p}$ & $10.39(0.38) \mathrm{rs}$ \\
& $\mathrm{E}-6$ & $2.41(0.35) \mathrm{k}$ & $0.72(0.07) \mathrm{n}$ & $0.59(0.05) \mathrm{p}$ & $10.57(1.29) \mathrm{s}$ \\
\hline
\end{tabular}

*Untreated. **Values in parentheses are the standard deviation; the same letters in each column indicate no statistical difference at the $95 \%$ confidence level among treatments

There were no significant differences found between the $\mathrm{N}-1$ and $\mathrm{C}-1$ treatments in the amount of absorption for both wood species, whereas there was a significant difference between E-6 and N-1 (Table 2). With regards to retention, there were considerable differences among the SNGW. There was no remarkable difference in density among the control, $\mathrm{N}-1$, and $\mathrm{C}-1$ treatments for black pine, whereas there was a noticeable difference between the E-6 and control. Moreover, there was no substantial difference among the three SNGW used to treat the Brutia pine. With regards to moisture content, there was no significant difference between the control, N-1, and C-1 treatments versus the E-6 treatment for black pine, while there was a significant difference among the E- $6, \mathrm{~N}-1$, and control treatments. For Brutia pine, there was no considerable difference between the $\mathrm{N}-1$ versus $\mathrm{C}-1$, and $\mathrm{E}-6$ versus $\mathrm{C}-1$, but there was a remarkable difference among the E-6, control, and N-1 treatments.

Based on these results, it was deduced that SNGW with higher concentrations of dissolved inorganics resulted in higher values of measured physical properties. Hence, the values measured for absorption, retention, density, and moisture content of the treated wood increased depending on which SNGW was used, and the concentration of dissolved salt species the SNGW contained. Such increases in physical properties were attributed to the dissolved salts in the SNGW affixing to the walls and lumens of the wood fibers, which increased the mass, as well as the volume (by swelling) of the wood. In the treatment with chemical preservative solutions it has been reported that chemical substances attached to the cell walls and lumens, resulting in an increase in mass and volume of the treated wood (Ozciftci and Batan, 2009). Ammoniacal-based waterborne wood preservatives are commonly used for wood protection (Yildiz et al., 2004). Ammonia can react with lignin and hemicelluloses of the wood cell wall (Ostmeyer, 1987; Winandy, 1995) to cause the wood to swell, and thereby increase the penetration of chemicals within its structure (Megnis et al., 2002). However, the absorption increase could also have been attributed to the expansion of lumens within the wood fibers, 
which absorb the SNGW into the wood structure (Ors and Keskin, 2001). The retention increase could result from affixation or precipitate of the wood preservatives to the cell walls, lumens, and intercellular spaces due to passage pairs performing the liquid flow within the wood structure (Ozciftci and Batan, 2009). Several investigations have stated that chemical treatments with different water-soluble preservatives, such as copper chrome boron (CCB) (Peker et al., 1999), CCA (Temiz et al., 2004; Sreeja and Edwin, 2013; Gezer and Cooper, 2016), and ammonium tetrafluoroborate (Atilgan and Peker, 2012), increase the retention value of the treated wood sample, which is also related to the concentration of the wood preservatives in the solution. The increase in moisture content of the treated versus the untreated sample may be caused by the absorption of water by the wood structure from the SNGW (Ors and Keskin, 2001). Moisture levels increase upon wood exposure to water-based preservatives, which could be due to the high amount of water that is used as the solvent (Yildiz et al., 2004). In addition, there are hygroscopic salts that absorb and retain water within the wood fiber walls, which causes the wood fibers to swell (Militz, 1993). Moreover, it has been reported that waterborne wood preservatives, such as borate (Simsek and Baysal, 2015), ammonium tetrafluoroborate (Atilgan and Peker, 2012), silicon dioxide (Dong et al., 2015), boric acid, borax, and sodium perborate (Toker, 2007), increase the density of the treated wood when compared to the untreated control. In certain studies, this increase in wood density due to preservative treatment has been shown to be statistically significant (Simsek and Baysal, 2015). Other defined parameters of wood preservatives, such as its toxicity against wood-destroying agents and its leaching, as well as aging, should be examined. Ors et al. (2005) and Var (2013) studied wood that was treated with ImersolAqua and SNGW, respectively, and reported that such treatments increased the values of retention, density, and moisture content. Hence, it was concluded that the results in Table 2 were consistent with the reported data in the literature.

\section{Mechanical properties}

The results for MOR, MOE, and CSPG for the pines treated with the SNGW is presented in Table 3. For black pine, the highest MOE values were obtained with the N1 treatment $\left(11175.22 \mathrm{~N} / \mathrm{mm}^{2}\right)$, while the $\mathrm{C}-1$ treatment gave the maximum MOR $\left(91.41 \mathrm{~N} / \mathrm{mm}^{2}\right)$ and CSPG $\left(42.31 \mathrm{~N} / \mathrm{mm}^{2}\right)$. The lowest MOR values were observed for the C-1 treatment $\left(88.05 \mathrm{~N} / \mathrm{mm}^{2}\right)$, whereas the lowest MOE and CSPG values were observed for the E-6 treatment $\left(9759.96 \mathrm{~N} / \mathrm{mm}^{2}\right.$ and $39.71 \mathrm{~N} / \mathrm{mm}^{2}$, respectively). Additionally, the MOR, MOE, and CSPG values of the untreated control samples were observed to be $99.55 \mathrm{~N} / \mathrm{mm}^{2}, 11365.18 \mathrm{~N} / \mathrm{mm}^{2}$, and $44.54 \mathrm{~N} / \mathrm{mm}^{2}$, respectively. For Brutia pine, the highest CSPG $\left(41.63 \mathrm{~N} / \mathrm{mm}^{2}\right.$ ) was observed for the C-1 treatment, whereas the N-1 treatment had the highest MOR $\left(86.82 \mathrm{~N} / \mathrm{mm}^{2}\right)$ and MOE $\left(11015.93 \mathrm{~N} / \mathrm{mm}^{2}\right)$. The lowest MOR $\left(79.71 \mathrm{~N} / \mathrm{mm}^{2}\right)$, MOE $\left(10484.65 \mathrm{~N} / \mathrm{mm}^{2}\right)$, and CSPG $\left(37.89 \mathrm{~N} / \mathrm{mm}^{2}\right)$ were noted for the E-6, C-1, and N-1 treatments, respectively.

Statistically significant differences for the MOR and CSPG values were noted for the treatments of both pines versus the untreated controls (Table 3). With regards to MOE values for black pine, there were significant differences in the C-1 and E- 6 treatments versus the control, but not for the $\mathrm{N}-1$ treatment. There were no significant differences observed among the geothermal water treatments for Brutia pine in the MOE values when compared to the control. Moreover, no significant differences in the MOR were noted among the geothermal water treatments, whereas there were significant differences detected between the E- 6 and N-1 treatments for Brutia pine. No significant 
differences in CSPG were observed between the N-1 and E- 6 treatments for black pine, and no significant differences were observed between the C- 1 and E- 6 treatments for Brutia pine. In general, these findings indicated that SNGW treatments significantly decreased the mechanical properties of the two wood species when compared to the respective untreated controls. This observation was attributed to the fact that geothermal salts or minerals tend to increase the equilibrium moisture content of the wood samples.

Table 3. Mechanical properties of pine wood species treated with SNGW

\begin{tabular}{|c|c|c|c|c|}
\hline Wood species & Geothermal water & $\operatorname{MOR}\left(\mathbf{N} / \mathbf{m m}^{2}\right)$ & $\operatorname{MOE}\left(\mathrm{N} / \mathbf{m m}^{2}\right)$ & CSPG (N/mm $\left.{ }^{2}\right)$ \\
\hline \multirow{4}{*}{ Black pine } & Control* & $99.55(5.60 * *) \mathrm{a}$ & $11365.18(966.70) \mathrm{c}$ & $44.54(2.48) \mathrm{f}$ \\
\hline & N-1 & 88.05 (3.68) b & $11175.22(637.15) \mathrm{c}$ & $40.16(1.80) \mathrm{g}$ \\
\hline & $\mathrm{C}-1$ & $91.41(4.27) \mathrm{b}$ & $10545.24(998.78) \mathrm{d}$ & $42.31(0.91) \mathrm{h}$ \\
\hline & E-6 & $89.92(4.84) b$ & $9759.96(691.44) \mathrm{e}$ & $39.71(1.36) \mathrm{g}$ \\
\hline \multirow{4}{*}{ Brutia pine } & Control* & $94.38(5.76) \mathrm{i}$ & $11193.62(683.80) 1$ & $43.23(2.24) \mathrm{m}$ \\
\hline & N-1 & $86.82(4.05) \mathrm{j}$ & 11015.93 (1079.94) 1 & $37.89(1.30) \mathrm{n}$ \\
\hline & $\mathrm{C}-1$ & $83.17(10.22) \mathrm{jk}$ & 10484.65 (1249.53) 1 & $41.63(0.98) \mathrm{o}$ \\
\hline & E-6 & $79.71(4.07) \mathrm{k}$ & $10892.84(1568.33) 1$ & $41.61(0.91) \mathrm{o}$ \\
\hline
\end{tabular}

*Untreated. **Values in parentheses are the standard deviation; the same letters in each column indicate no statistical difference at the $95 \%$ confidence level among treatments

These results indicated that all of the treated samples had lower mechanical strength values when compared to the untreated control samples. This decrease could also have been due to the acidity of the SNGW, which caused some hydrolysis of the wood structure. Bozkurt and Erdin (1997) reported that if the moisture content of wood increases at temperatures above $0{ }^{\circ} \mathrm{C}$, then the resistance of wood against the forces causing deformation can decrease, and the chemical solutions whose $\mathrm{pH}$ value is in the acidic zone can strengthen the hydrolysis of wood polysaccharides, and therefore, lower the mechanical properties of wood materials. The SNGW contain many chemical components that are commonly found in waterborne wood preservation formulations (Var, 2009). Such substances account for more than half (55\% to 87\%) of the total chemicals contained in SNGW (Var and Yaldiz, 2017). Wood treatments with such chemicals generally decrease the mechanical properties of the substrate because the waterborne preservatives physically react with the cellular wood components (Winandy, 1996). Many acidic substances used in waterborne formulations hydrolyze wood sugar components, which can decrease the strength values of the wood structure (Hamel, 1988). It has been reported that different concentration levels of waterborne wood preservatives result in more than a $20 \%$ reduction in CSPG values for Calabrian pine and beech (Toker et al., 2008). It has been determined that waterborne treatments have caused some decreases in other mechanical properties of wood materials (Laks and Palardy, 1990). The effect of different waterborne wood preservatives is related to the chemistry of the system and the severity of the fixation reaction (Winandy, 1996). Waterborne systems, such as borates, decrease the CSPG and MOR values of the impregnated wood. As the borate concentration in this system increases, the CSPG and MOR values of the impregnated wood decrease (Simsek et al., 2010). In other studies, it has been reported that waterborne formulations, such as boric acid (Colakoglu et al., 2003; Ayrilmis et al., 2005), borate (Wu et al., 2002; Simsek et al., 2010), CCA (Hesp 
and Watson, 1964; Yildiz et al., 2004), and boron compounds (Toker et al., 2009), decreased the MOR and MOE of the preserved wood compared to the untreated control.

The measured results in Table 3 were compared to the results in certain studies; for example, Sen et al. (2017) and Var et al. (2017) studied the properties of wood treated with the geothermal and rich mineral waters, and geothermal hot waters, respectively. It was reported that such treatments decreased the values of MOR, MOE, and CSPG. The data in Table 3 indicated that the treatment of pine woods with SNGW lowered their mechanical strength values. Hence, it was concluded that these observations are consistent with the findings reported in the aforementioned studies. According to these results, it could be useful that the wood materials from pine woods treated with SNGW are used under the conditions of air-dry moisture content for the potential use areas exposed to the effects of mechanical strengths such as MOR and CSPG. However, for potential applications of wood materials, the users of pine woods should consider the physical and mechanical properties such as strength type and moisture content for pine woods treated with such SNGW.

\section{Shrinking properties}

Table 4 presents the data for shrinking tests for both pine wood species treated with SNGW. For black pine, the lowest shrinking values for the tangential of $5.89 \%$ and anisotropic of 1.19 were measured for the $\mathrm{N}-1$ treatment, while the $\mathrm{C}-1$ and $\mathrm{E}-6$ treatments gave the minimum shrinking values for the radial $(4.49 \%)$ and volumetric $(10.36 \%)$, respectively. Also, the C-1 treatment gave the highest tangential $(6.18 \%)$ and anisotropic (1.38) shrinking values, while the maximum radial $(4.96 \%)$ and volumetric $(10.77 \%)$ shrinking were obtained with the N-1 treatment. For Brutia pine, the lowest radial $(5.29 \%)$ and volumetric $(12.00 \%)$ shrinking were observed for the $\mathrm{C}-1$ treatment, whereas the E-6 treatment yielded the lowest tangential (7.02\%) and anisotropic (1.13) shrinking. Furthermore, the N-1 treatment gave the highest measured shrinking values of $7.72 \%$ (tangential) and $13.17 \%$ (volumetric), while the highest radial $(6.25 \%)$ and anisotropic (1.35) shrinking were noted for the E-6 and C-1 treatments, respectively.

Table 4. Shrinking properties of pine wood species treated with SNGW

\begin{tabular}{c|c|c|c|c|c}
\hline $\begin{array}{c}\text { Wood } \\
\text { species }\end{array}$ & $\begin{array}{c}\text { Geothermal } \\
\text { waters }\end{array}$ & $\begin{array}{c}\text { Radial shrinking } \\
(\boldsymbol{\%})\end{array}$ & $\begin{array}{c}\text { Tangential } \\
\text { shrinking (\%) }\end{array}$ & $\begin{array}{c}\text { Volumetric } \\
\text { shrinking (\%) }\end{array}$ & $\begin{array}{c}\text { Anisotropic } \\
\text { shrinking }\end{array}$ \\
\hline & Control* $^{*}$ & $5.52\left(0.18^{* *}\right) \mathrm{a}$ & $6.94(0.22) \mathrm{d}$ & $12.20(0.32) \mathrm{g}$ & $1.26(0.04) \mathrm{j}$ \\
Black pine & $\mathrm{N}-1$ & $4.96(0.22) \mathrm{b}$ & $5.89(0.15) \mathrm{e}$ & $10.77(0.28) \mathrm{h}$ & $1.19(0.06) \mathrm{k}$ \\
& $\mathrm{C}-1$ & $4.49(0.10) \mathrm{c}$ & $6.18(0.20) \mathrm{f}$ & $10.45(0.29) \mathrm{i}$ & $1.38(0.05) \mathrm{l}$ \\
& $\mathrm{E}-6$ & $4.53(0.14) \mathrm{c}$ & $6.13(0.17) \mathrm{f}$ & $10.36(0.28) \mathrm{i}$ & $1.35(0.05) \mathrm{l}$ \\
\hline & Control* & $6.08(0.33) \mathrm{m}$ & $7.48(0.36) \mathrm{p}$ & $13.11(0.59) \mathrm{r}$ & $1.23(0.08) \mathrm{t}$ \\
& $\mathrm{N}-1$ & $5.91(0.31) \mathrm{m}$ & $7.72(0.36) \mathrm{p}$ & $13.17(0.65) \mathrm{r}$ & $1.31(0.10) \mathrm{u}$ \\
Brutia pine & $\mathrm{C}-1$ & $5.29(0.27) \mathrm{n}$ & $7.10(0.38) \mathrm{q}$ & $12.00(0.40) \mathrm{s}$ & $1.35(0.07) \mathrm{u}$ \\
& $\mathrm{E}-6$ & $6.25(0.35) \mathrm{o}$ & $7.02(0.47) \mathrm{q}$ & $12.83(0.50) \mathrm{r}$ & $1.13(0.09) \mathrm{w}$ \\
\hline
\end{tabular}

*Untreated. **Values in parentheses are the standard deviation; the same letters in each column indicate no statistical difference at the $95 \%$ confidence level among treatments

Statistically significant differences for the shrinking values were found for the treatments of black pine versus the non-treated controls, except for the C-1 and E-6 
treatments (Table 4). The similar situations were observed between the $\mathrm{N}-1$ treatment and other geothermal water treatments for the black pine. For Brutia pine, the significant differences between the C-1 and E-6 treatments were found for all shrinking values, excluding the $\mathrm{N}-1$ treatment, when compared to the untreated control. With regards to shrinking, for Brutia pine, there were significant differences among all geothermal water treatments in the radial values, while no significant differences in the volumetric values were found between the N-1 and E-6 treatments; no significant differences in the anisotropic values were also observed between the $\mathrm{N}-1$ and $\mathrm{C}-1$ treatments. Furthermore, the significant differences between the C-1 and E- 6 treatments were noted for the radial, volumetric, and anisotropic shrinking for Brutia pine, while no significant differences were yielded for the tangential shrinking.

Here results showed that the SNGW treatment significantly decreased the shrinking properties of treated samples versus the non-treated samples for both pine woods. For black pine, the anisotropic shrinking reduced in the $\mathrm{N}-1$ treatment, whereas it increased in the E- 6 treatment; but the vice versa was for Brutia pine. Moreover, for black pine, the $\mathrm{N}-1$ treatment significantly reduced the tangential and anisotropic shrinking versus the $\mathrm{C}-1$ and E-6 treatments, while it increased the radial and volumetric shrinking. Also, both the C-1 and E- 6 treatments had not indicated a significant effect on the shrinking properties of black pine. For Brutia pine, the E-6 treatment significantly increased the radial shrinking when compared to the $\mathrm{N}-1$ and $\mathrm{C}-1$ treatments, whereas the $\mathrm{C}-1$ treatment significantly had reduced the volumetric shrinking versus the $\mathrm{N}-1$ treatment. However, the N-1 treatment had significantly improved tangential and anisotropic shrinking of Brutia pine when compared to the E-6 treatment.

According to these findings, it was observed that the shrinking values of pine woods treated with the distilled water after the SNGW treatment lowered when compared to the non-treated control wood. This lowing could be due to the following: In the SNGW, the geothermal chemicals that are initially absorbed by pine wood could plasticize the lumen linings and cell walls within the wood structure (Stamm, 1955). The woody cells that are lose its plasticity during evaporation of the SNGW from the lumen system within the wood structure could force the more plastic cells to shrink inwards, towards them, and cause an overall shrinking in the wood volume (Pollisco et al., 1971.

The results in Table 4 were compared to the findings in some studies; for instance, Bozkurt and Erdin (1997), and Bozkurt et al. (1993) had studied on the wood technology, and wood impregnation technique, respectively. It was reported that the shrinking values of black pine are $5.60 \%$ for the radial, $8.20 \%$ for the tangential, $13.90 \%$ for the volumetric, and 1.46 for the anisotropic. Likewise, it was nopted that the shrinking values of Brutia pine are $4.90 \%$ for the radial, $6.80 \%$ for the tangential, $12.20 \%$ for the volumetric, and 1.39 for the anisotropic. Also, some of earlier studies had investigated the properties of wood impregnated with the ammonia (Bariska, 1975; Coles and Walker, 1978), the liquid ammonia (Stamm and Seborg, 1936), and the ammonia vapor (Pollisco et al., 1971). It was noted that such treatments decreased the shrinking properties of wood. The obtained results in Table 4 showed that SNGW treatments lowered the shrinking values of pine woods. Hence, it was concluded that these results in Table 4 were agree with the findings in the aforesaid studies. According to these results, it could be advantageous that the pine woods treated with SNGW is utilized under the low relative humidity conditions for potential uses. Otherwise, in such treated pine woods, it could be an overall volumetric shrinking and dimensional change. 


\section{Swelling properties}

The results of swelling tests for both pine wood treated with the SNGW is shown in Table 5. For black pine, the lowest radial $(4.15 \%)$ and volumetric $(11.20 \%)$ swelling values were obtained with the $\mathrm{N}-1$ treatment, while the E-6 treatment gave the minimum volumetric $(11.45 \%)$ and anisotropic (1.37) swelling values. The highest tangential and volumetric swelling values were measured for the $\mathrm{C}-1$ treatment $(7.08 \%$ and $12.00 \%$, respectively), whereas the E- 6 and $\mathrm{N}-1$ treatments had the highest radial (4.72\%) and anisotropic (1.63) swelling values, respectively. For Brutia pine, for the radial, tangential and volumetric swelling, the $\mathrm{C}-1$ treatment gave the lowest values $(5.08 \%, 7.20 \%$, and $12.65 \%$, respectively), while the highest values were observed to be $5.76 \%, 7.79 \%$, and $14.00 \%$, respectively (with the N-1 treatment). Additionally, for the anisotropic swelling, the highest value was noted for the C-1 treatment (1.43), whereas it was reported that the minimum value is 1.28 for the E- 6 treatment.

Table 5. Swelling properties of pine wood species treated with SNGW

\begin{tabular}{c|c|c|c|c|c}
\hline $\begin{array}{c}\text { Wood } \\
\text { species }\end{array}$ & $\begin{array}{c}\text { Geothermal } \\
\text { waters }\end{array}$ & $\begin{array}{c}\text { Radial swelling } \\
(\boldsymbol{\%})\end{array}$ & $\begin{array}{c}\text { Tangential } \\
\text { swelling (\%) }\end{array}$ & $\begin{array}{c}\text { Volumetric } \\
\text { swelling (\%) }\end{array}$ & $\begin{array}{c}\text { Anisotropic } \\
\text { swelling }\end{array}$ \\
\hline & Control* & $6.61\left(0.18^{* *}\right) \mathrm{a}$ & $7.57(0.18) \mathrm{d}$ & $14.60(0.30) \mathrm{h}$ & $1.15(0.03) \mathrm{l}$ \\
& $\mathrm{N}-1$ & $4.15(0.09) \mathrm{b}$ & $6.76(0.21) \mathrm{e}$ & $11.20(0.29) \mathrm{i}$ & $1.63(0.06) \mathrm{m}$ \\
Black pine & $\mathrm{C}-1$ & $4.51(0.07) \mathrm{c}$ & $7.08(0.23) \mathrm{f}$ & $12.00(0.19) \mathrm{j}$ & $1.57(0.06) \mathrm{n}$ \\
& $\mathrm{E}-6$ & $4.72(0.11) \mathrm{c}$ & $6.46(0.16) \mathrm{g}$ & $11.45(0.28) \mathrm{k}$ & $1.37(0.04) \mathrm{o}$ \\
\hline & Control* & $6.20(0.27) \ddot{\mathrm{o}}$ & $9.07(0.34) \mathrm{r}$ & $15.85(0.32) \mathrm{t}$ & $1.47(0.10) \mathrm{v}$ \\
& $\mathrm{N}-1$ & $5.76(0.47) \mathrm{p}$ & $7.79(0.38) \mathrm{s}$ & $14.00(0.76) \mathrm{u}$ & $1.36(0.11) \mathrm{yz}$ \\
& $\mathrm{C}-1$ & $5.08(0.48) \mathrm{q}$ & $7.20(0.37) \mathrm{s}$ & $12.65(0.67) \mathrm{u}$ & $1.43(0.15) \mathrm{vy}$ \\
& $\mathrm{E}-6$ & $5.72(0.51) \mathrm{p}$ & $7.27(0.30) \mathrm{s}$ & $13.41(0.67) \mathrm{w}$ & $1.28(0.10) \mathrm{z}$ \\
\hline
\end{tabular}

*Untreated. **Values in parentheses are the standard deviation; the same letters in each column indicate no statistical difference at the $95 \%$ confidence level among treatments

For the swelling values, the statistically significant differences were observed for the treatments of both pine woods versus the non-treated controls (Table 5). For black pine, there were significant differences observed among the SNGW treatments in the swelling values. For Brutia pine, with regards to radial swelling, there were remarkable differences between the N-1 and E- 6 treatments vesus the C-1 treatment, whereas there was no significant difference between the E- 6 and N-1 treatments. Besides, significant differences in the tangential swelling were observed between the C-1 and E-6 treatments vesus the $\mathrm{N}-1$ treatment for Brutia pine, while no significant differences were observed between the E- 6 and C-1 treatments. Moreover, significant differences in the anisotropic swelling were noted between the E-6 and C-1 geothermal waters used to treat the Brutia pine, whereas there were no considerable difference observed between the $\mathrm{N}-1$ treatment versus the $\mathrm{C}-1$ and $\mathrm{E}-6$ treatments.

The data noted in Table 5 saw that the swelling values of pine wood samples treated with the distilled water after the SNGW treatment decreased when compared to the untreated control samples. One of the major disadvantages of wood material is also its swelling due to the moisture content of the air. The wood material swells when used under the high moisture content conditions. Likewise, the same cases are also observed in the wood materials treated with the hygroscopic wood preservative salts. But, the 
swelling values of wood treated with the hygroscopic chemicals are less than that of the untreated wood (Bozkurt et al., 1993). The decrease of a general swelling in the volume of wood treated with the SNGW could be from the hygroscopic geothermal chemicals absorbed by the woody cells within the wood structure. The strength of hydrogen bonding could be decrease as the absorption of hygroscopic chemicals increases; consequently, the water sorptive capacity of the cell wall and the volumetric swelling of wood in water could be decrease with increasing of the hygroscopic chemical absorption (Coles and Walker, 1978). Also, the swelling of wood in water could be related to hydrogen bonding and by changes in the cellulose structure (Stamm, 1955). Compared to the untreated wood, this swelling phenomenon could be due to the cellulose chains that are the less swelling within the SNGW-treated wood structure, and the cellulose chains that remain in the less swollen state within this structure after the SNGW evaporation (Stamm and Seborg, 1936).

The results in Table 5 were compared to the results of earlier studies; for example, some workers had studied the properties of wood treated with the ammonia (Coles and Walker, 1978), the liquid ammonia (Stamm and Tarkow, 1955), and the liquid ammonia-solvent combinations (Pentoney, 1966). It was reported that such treatments decreased the swelling properties of wood. Our own observations in Table 5 indicated that the SNGW treatments lowered the swelling values of pine woods. Hence, it was concluded that the results of Table 5 are consistent with these studies. According to the results noted here, it could be helpful that the pine wood species treated with such SNGW is not used under the high moisture content conditions. If not, it could be a general volumetric swelling and dimensional modify for such treated pine wood materials.

\section{Conclusions}

This study investigated how the impregnation of black and Brutia pine wood species with three different SNGW from Turkey (as environmentally safe resources) affected the physical, mechanical, shrinking, and swelling properties of the wood. The absorption and retention values for all treated pine wood samples significantly increased depending on the concentration of the mineral salts found in the SNGW. The highest physical values were observed for the E- 6 treatment, whereas the lowest physical values were observed for the N-1 treatment.

In general, the SNGW treatments increased the values of density and moisture content of the two pine wood species, but decreased the values of MOR, MOE, CSPG, shrinking, and swelling. The decreases in the MOR, MOE, CSPG, shrinking, and swelling of the treated pine woods were higher compared to the non-treated wood, but the increases in density and moisture content were lower. For the E-6 treatment, the increases in density and moisture content were higher than those of the other treatments. For the N-1 treatment, the decreases in MOR, MOE, and CSPG were less than those of the other SNGW treatments. For example, in the E-6 treatment the density increased $7.69 \%$ and $3.51 \%$ for black pine and Brutia pine, respectively; for the N-1 and C-1 treatments, the increases in density were $1.92 \%$ and $5.77 \%$ for black pine, respectively, and were $1.79 \%$ and $3.75 \%$ for Brutia pine, respectively. Similar increases were also observed for the moisture content values. In the N-1 treatment, the MOR values decreased $11.55 \%$ and $8.01 \%$ for black pine and Brutia pine, respectively, whereas for the $\mathrm{C}-1$ and E-6 treatments, the decreases were $8.14 \%$ and $9.67 \%$ for black pine, 
respectively, and the decreases were $11.88 \%$ and $15.54 \%$ for Brutia pine, respectively. Similar reductions were also observed for the MOE, CSPG, shrinking, and swelling.

Based on these laboratory results, the effects of SNGW on the physical, mechanical, shrinking, and swelling properties of pine woods can be directly related to several important factors related to: wood type and quality; saltwater absorption and mineral retention amounts within the wood; variety and content of chemical compounds within the SNGW; treatment method used; wood drying temperature; and wood treatment processing factor.

The pine wood materials treated with such SNGW can be used in the application areas, where no dense humidity, static bending and pressure parallel to grain effects for long periods. Therefore, for such application areas, the users or designers should consider the loading type and humidity criteria calculation for pine wood materials treated with such natural salt waters.

This study is not an indication that the SNGW can be used as wood preservatives. Therefore, for the examination protective performance of SNGW treatment, some analyzes such as decay test, leaching test, and weathering test could be done. Because those tests could be a requirement to determine the usability of SNGW as a wood preservative.

Acknowledgments. The authors are grateful for the support from the TR Suleyman Demirel University Department of Scientific Research Projects Coordination (Grant No. 3365-YL1-12).

\section{REFERENCES}

[1] Akkuş, İ., Akıllı, H., Ceyhan, S., Dilemre, A., Tekin, Z. (2005): Turkey Geothermal Resources Inventory. - General Directorate of Mineral Research and Exploration's Publications, Inventory Series-201, Ankara, Turkey (in Turkish).

[2] ASTM D1413-07e1 (2007): Standard Test Method for Wood Preservatives by Laboratory Soil Block Cultures. - ASTM International, West Conshohocken, PA.

[3] Atilgan, A., Peker, H. (2012): Effects of different wood preservatives on the some physical properties of wood species used in furniture and building industry. - Artvin Coruh Univ. J. of Forestry Faculty 13(1): 67-78.

[4] Ayrilmis, N., Kartal, S. N., Laufenberg, T. L., Winandy, J. E., White, R. H. (2005): Physical and mechanical properties and fire, decay, and termite resistance of treated oriented strandboard. - Forest Products Journal 55(5): 74-81.

[5] Bariska, M. (1975): Collapse Phenomena in Beech wood during and after $\mathrm{NH}_{3}$ Impregnation. - Wood Science and Technology 9: 293-306.

[6] Bozkurt, A. Y., Erdin, N. (1997): Textbook of Wood Technology. - Istanbul University Faculty of Forestry Publications, Istanbul, Turkey (in Turkish).

[7] Bozkurt, A. Y., Goker, Y., Erdin, N. (1993): Textbook of Wood Impregnation Technique. - Istanbul University Faculty of Forestry Publications, Istanbul, Turkey (in Turkish).

[8] Colakoglu, G., Colak, S., Aydin, I., Yildiz, U. C., Yildiz, S. (2003): Effects of boric acid treatment on mechanical properties of laminated beech veneer lumber. - Silva Fennica 37(4): 505-510. DOI: 10.14214/sf.488.

[9] Coles, R. W., Walker, J. C. F. (1978): Induced shrinkage and structural reorganisation in ammonia-treated wood of Corsican pine. - Wood and Fiber 10 (1): 39-57.

[10] Degirmentepe, S., Baysal, E., Turkoglu, T., Toker, H., Deveci, I. (2015): Some properties of Turkish sweetgum balsam (Styrax liquidus) impregnated oriental beech wood. Part II: Decay resistance, mechanical and thermal properties. - Wood Research 60(4): 591-604. 
[11] Dong, Y., Yan, Y., Zhang, S., Li, J., Wang, J. (2015): Flammability and physicalmechanical properties assessment of wood treated with furfuryl alcohol and nano-SiO $\mathrm{S}_{2}$ European J. of Wood and Wood Prod. 73(4): 457-464. DOI: 10.1007/s00107-015-0896-y.

[12] Gezer, E., Cooper, P. A. (2016): Effects of wood species and retention levels on removal of copper, chromium, and arsenic from CCA-treated wood using sodium hypochlorite. Journal of Forest Research 27(2): 433-442. DOI: 10.1007/s11676-015-0172-3.

[13] Hamel, M. P. (1988): Wood Protection Techniques and the Use of Treated Wood in Construction. Proceedings. - Forest Products Research Society, Madison, WI, pp. 54-62.

[14] Hesp, T., Watson, R. W. (1964): The effects of water-borne preservatives applied by vacuum pressure methods on the strength properties of wood. - Wood 29(6): 50-53.

[15] Ilgar, R. (2005): The view of dualist approach on geothermal sources. - Electronic Journal of Social Sciences 4(13): 88-98 (in Turkish).

[16] ISO 3129 (2012): Wood-Sampling Methods and General Requirements for Physical and Mechanical Testing of Small Clear Wood Specimens. - International Organization for Standardization, Geneva, Switzerland.

[17] ISO 4469 (1981): Wood-Determination of Radial and Tangential Shrinkage. International Organization for Standardization, Geneva, Switzerland.

[18] ISO 4858 (1982): Wood-Determination of Volumetric Shrinkage. - International Organization for Standardization, Geneva, Switzerland.

[19] ISO 4859 (1982): Wood-Determination of Radial and Tangential Swelling. International Organization for Standardization, Geneva, Switzerland.

[20] ISO 4860 (1982): Wood-Determination of Volumetric Swelling. - International Organization for Standardization, Geneva, Switzerland.

[21] ISO 13061-1 (2014): Physical and Mechanical Properties of Wood - Test Methods for Small Clear Wood Specimens - Part 1: Determination of Moisture Content for Physical and Mechanical Tests. - International Organization for Standardization, Geneva, Switzerland.

[22] ISO 13061-2 (2014): Physical and Mechanical Properties of Wood - Test Methods for Small Clear Wood Specimens - Part 2: Determination of Density for Physical and Mechanical Tests. - International Organization for Standardization, Geneva, Switzerland.

[23] ISO 13061-3 (2014): Physical and Mechanical Properties of Wood - Test Methods for Small Clear Wood Specimens - Part 3: Determination of Ultimate Strength in Static Bending. - International Organization for Standardization, Geneva, Switzerland.

[24] ISO 13061-4 (2014): Physical and Mechanical Properties of Wood - Test Methods for Small Clear Wood Specimens - Part 4: Determination of Modulus of Elasticity in Static Bending. - International Organization for Standardization, Geneva, Switzerland.

[25] ISO 13061-17 (2017): Physical and Mechanical Properties of Wood - Test Methods for Small Clear Wood Specimens - Part 17: Determination of Ultimate Stress in Compression Parallel to Grain. - International Organization for Standardization, Geneva, Switzerland.

[26] Kantay, R. (1978): Properties of steamed wood material (Translation from H. Kübler). Istanbul University Journal of Forestry Faculty B (28): 231-240 (in Turkish).

[27] Keskin, H., Daglioglu, N. (2016): Effects of Tanalith E impregnation substance on bending strengths and modulus of elasticity in bending of some wood types. - Artvin Coruh Univ. J. of Forestry Faculty 17(1): 62-69. DOI: 10.17474/acuofd.90044.

[28] Keskin, H., Atar, M., Erturk, N. S., Colakoglu, M. H., Korkut, S. (2013): Mechanical properties of rowan wood impregnated with various chemical materials. - International Journal of Physical Science 8(2): 73-82. DOI: 10.5897/IJPS12.688.

[29] Laks, P. E., Palardy, R. D. (1990): The development of borate-containing flakeboard. Proceedings of the First International Conference on Wood Protection with Diffusible Preservatives, Forest Products Research Society, Madison, WI, pp. 76-79.

[30] Megnis, M., Olsson, T., Varna, J., Lindberg, H. (2002): Mechanical performance of linseed oil impregnated pine as correlated to the take-up level. - Wood Science and Technology 36(1): 1-18. DOI: 10.1007/s002260100120. 
[31] Militz, H. (1993): Treatment of timber with water soluble dimethylol resins to improve their dimensional stability and durability. - Wood Science and Technology 27(5): 347355. DOI: 10.1007/BF00192221.

[32] Mourant, D., Yang, D. Q., Roy, C. (2007): Decay resistance of PF-pyrolytic oil resin treated wood. - Forest Products Journal 57(5): 30-35.

[33] Mourant, D., Yang, D. Q., Rield, B., Roy, C. (2008): Mechanical properties of wood treated with PF-pyrolytic oil resins. - Holz als Roh- und Werkstoff 66: 163-171. DOI: 10.1007/ s00107-007-0221-5.

[34] Ors, Y., Keskin, H. (2001): Textbook of Wood Material Technology. - Nobel Publishing, Ankara, Turkey (in Turkish).

[35] Ors, Y., Atar, M., Keskin, H., Yavuzcan, H. G. (2005): Impacts of impregnation with imersol aqua on the modulus of elasticity in bending. - Journal of Applied Polymer Science 99(6): 3210-3217. DOI: 10.1002/app.22035.

[36] Ostmeyer, J. G. (1987): Chemical and mechanical evaluation of southern pine wood treated with chromated copper arsenate. - Ph.D. Dissertation, Auburn Univ., USA.

[37] Ozciftci, A., Batan, F. (2009): Effect of some mechanical properties on wood materials impregnated with waste boron oil. - Journal of Polytechnic 12(4): 287-292. DOI: 10.2339/2009.12.4, 287-292.

[38] Peker, H., Sivrikaya, H., Baysal, E., Yalınkılıç, M. (1999): Static bending strength of wood treated with fire retardant and water repellent preservation chemicals. - Pamukkale University Journal of Engineering Sciences 5(1): 975-982.

[39] Pentoney, R. E. (1966): Liquid ammonia-solvent combinations in wood plasticization: Properties of treated wood. - Ind. Eng. Chem. 5(2): 105-110.

[40] Pollisco, F. S., Skaar, C., Davidson, R. W. (1971): Some physical properties of maple wood treated with ammonia vapor. - Wood Sciences 4(2): 65-70.

[41] Sen, S., Var, A. A., Oz, A. (2017): The effects of antifungal, antitermitic and some physical-mechanical properties of geothermal and rich mineral waters as environmental protectors in wood material. - Proceedings of the Second International Symposium on Multidisciplinary Studies, Rome, Italy, pp. 153-169.

[42] Simsek, H., Baysal, E. (2015): Some physical and mechanical properties of borate-treated oriental beech wood. - Drvna Industrija 66(2): 97-103. DOI: 10.5552/drind.2015.1356.

[43] Simsek, H., Baysal, E., Peker, H. (2010): Some mechanical properties and decay resistance of wood impregnated with environmentally-friendly borates. - Construction and Building Materials 24(11): 2279-2284. DOI: 10.1016/j.conbuildmat.2010.04.028.

[44] Sreeja, A., Edwin, L. (2013): Physical barriers: an alternative to prevent negative impacts of chemically treated wood. - Indian Academy of Wood Science 10(2): 140-146. DOI: 10.1007/s13196-013-0106-7.

[45] Stamm, A. J. (1955): Swelling of wood and fiberboards in liquid ammonia. - Forest Products Journal 5(6): 413-416.

[46] Stamm, A. J., Seborg, R. M. (1936): Minimizing wood shrinkage and swelling: treating with synthetic resin-forming materials. - Ind. Eng. Chem. 28(10): 1165-1169.

[47] Temiz, A., Yildiz, U. C., Gezer, E. D., Yildiz, S. (2004): Interaction of copper based preservatives with wood. - Artvin Coruh Univ. J. of Forestry Faculty 5(2): 204-211.

[48] Toker, H. (2007): Determination of effects of boron compounds on some physical mechanical and biological properties of wood. - Ph.D. Dissertation, Gazi Univ., Ankara, Turkey (in Turkish).

[49] Toker, H., Baysal, E., Ozcifci, A., Altinok, M., Sonmez, A., Yapici, F. (2008): An investigation on compression parallel to grain values of wood impregnated with some boron compounds. - Wood Research Journal 53(4): 59-68.

[50] Toker, H., Baysal, E., Simsek, H., Senel, A., Sonmez, A., Altinok, M. (2009): Effects of some environmentally-friendly fire-retardant boron compounds on modulus of rupture and modulus of elasticity of wood. - Wood Research Journal 54(1): 77-88. 
[51] Var, A. A. (2009): Quantative of potential wood preservatives in geothermal fluids and their suitableness for wood impregnation treatment. - Suleyman Demirel University Faculty of Forestry Journal A 1: 184-197.

[52] Var, A. A., Yaldiz, M. Y. (2017): Wood impregnants potential of Alangullu, Camkoy and Germencik (Aydin) geothermal resources and their effects on absorption, retention and density of black pine wood. - El-Cezerî J. of Science and Engineering 4(3): 482-496.

[53] Var, A. A., Goncu, D., Karsantiozu, F. (2013): Investigation of absorption, retention and swelling in Izmir-Doğanbey geothermal waters-treated pine wood. - Suleyman Demirel University Faculty of Forestry Journal 14(2): 127-133.

[54] Var, A. A., Kardas, I., Genc, A. (2015): Determination of wood impregnant potential, effects on absorption, retention and density in wooden of Kütahya-Simav geothermal waters. - Turkish Journal of Forestry 16(1): 42-49.

[55] Var, A. A., Yalcin, O. U., Soyguder, A. (2017): Effects of geothermal hot water treatment on rate of water absorption, modulus of elasticity, compressive strength parallel to grain of brutian pine wood: a case study from Sakarya, Turkey. - Turkish Journal of Forestry 18(4): 314-320. DOI: 10.18182/tjf.340453.

[56] Ville, L., Kimmo, H., Timo, K. (2014): The effects of preservatives on the properties of wood after modification. - Baltic Forestry 20(1): 189-203.

[57] Winandy, J. E. (1995): Effects of waterborne preservative treatment on mechanical properties: a review. - Proceedings of the Ninety-First Annual Meeting of American Wood-Preservers' Association, New York, pp. 17-34.

[58] Winandy, J. E. (1996): Effects of Treatment, Incising, and Drying on Mechanical Properties of Timber. - In: Ritter, M. A., Duwadi, S., Lee, P., Hilbrich, D. (eds.) Proceedings of the National Conference on Wood Transportation Structures - New Wood Treatments. Department of Agriculture Forest Products Laboratory, Forest Service, Madison, WI, pp. 371-378.

[59] Wu, Q., Lee, S., Lee, J. N. (2002): Mechanical, physical, and biological properties of borate-modified oriented strandboard. - Proceedings of the International Conference on Advances in Building Technology, Hong-Kong, China, pp. 137-144. DOI: 10.1016/B978-008044100-9/50018-8.

[60] Yaldiz, M. Y., Var, A. A. (2017): Investigation of some properties of black pine (Pinus nigra Arnold.) sapwood impregnated with geothermal waters of Turkey's Aydin regional. - Proceedings of the $3^{\text {rd }}$ ASM International Congress of Agriculture and Environment, Abstract Book-1, Antalya, Turkey.

[61] Yildiz, U. C., Temiz, A., Gezer, E. D., Yildiz, S. (2004): Effects of the wood preservatives on mechanical properties of yellow pine (Pinus sylvestris L.) wood. Building and Environment 39(9): 1071-1075. DOI: 10.1016/j.buildenv.2004.01.032. 